\title{
Effect of Vegetative Shoot Thinning on Growth, Yield and Bunch Quality of Black Monukka and Red Globe Grape Cultivars
}

Ghada Sh. Shaker

Viticulture Research Department, Horticulture Research

Institute, Agricultural Research Centre, Cairo, Egypt.

\begin{abstract}
7 HIS INVESTIGATION was conducted for two successive seasons $(2010 \& 2011)$ in a private vineyard located at $58 \mathrm{Km}$ of Cairo-Alexandria desert road to study the possibility of improving vegetative growth, yield and bunch quality through the application of shoot thinning on Black Monukka and Red Globe grapevines. The vines were ten-year-old, grown in a sandy loam soil, spaced at 2 X 3 meters apart, irrigated by the drip irrigation system, cane-pruned (6 canes X 12 buds/cane) and trellised by Spanish Parron system. Four treatments were applied before the beginning of bloom as follows, control (untreated vines), removal of four main vegetative shoots, removal of eight main vegetative shoots and removal of twelve main vegetative shoots.
\end{abstract}

The obtained result showed that all treatments were effective in increasing the number of bunches/vine, average bunch weight and yield. Removal of twelve main vegetative shoots of Black Monukka grapevines and removal of eight main vegetative shoots of Red Globe grapevines improved the physical characteristics of the bunches, physical and chemical properties of berries, morphological characteristics of vegetative growth, leaf content of total chlorophyll and cane content of total carbohydrates as compared with the control.

The microclimate study indicated that removal of twelve main vegetative shoots of Black Monukka and Red Globe grapevines resulted in the highest values of air temperature and light intensity as compared to the untreated vines (control).

Keywords: Black, Monukka, Red, Globe, Grapevines, Yield, Chlorophyll, Microclimate

Black Monukka grapevines are known to have relatively high vine vigour in relation to yield (Marwad, 2002). The quality of the clusters and berries is not rather good, since this cultivar is characterized by the production of medium berries and large and loose bunches which is negatively reflected on bunch quality.

Red Globe grapevines are characterized by having a considerably low vine vigour, which is not proportion to yield (Gasser, 2006). The good production of yield of this cultivar faces some challenges, depression of vegetative growth, 
increasing the possibility of berry exposure to sunburn damage and irregular coloration of the berry, there defects are undoubtedly reflected on reducing bunch quality.

Summer pruning can be used as a useful means for maintaining vine balance between vegetative growth and productivity. For low to high vigour vineyards, summer pruning on fruit zone and leaf removal may be sufficient to improve the microclimate of the vine (Freese, 1988). Many workers reviewed the effect of summer pruning on growth and fruiting of various grape cvs. They emphasized the necessity of summer pruning for enhancing growth and production of grapes (Reynolds, 1989, Wolf et al., 1990, Abd El-Wahab, et al., 1997 and Alia et al., 2001).

Shoot thinning can reduce canopy density, although the ideal shoot number per meter of row is dependent on cultivar and site (Reynolds et al., 2005). Shoot thinning helps to establish balance after the grower has safely diagnosed the variability that comes with late frosts, blind nodes, and prolific non-count buds (Morris et al., 2004). When shoot spacing is optimized, the vine is more efficient at radiation interception (Smart, 1988). Appropriate shoot spacing can improve fruit composition in vinifera (Reynolds et al., 1994, Smart 1988 and Reynolds et al., 2005). For interspecific hybrids, shoot thinning improved soluble solids in Chancellor by $5 \%$ over a 3-year average (Morris et al., 2004).

The aim of this study was to improve vegetative growth, yield and bunch quality through the removal of some vegetative shoot on Black Monukka and Red Globe grape cultivars.

\section{Material and Methods}

This investigation was conducted for two successive seasons (2010 \& 2011) in a private vineyard located at $58 \mathrm{Km}$ of Cairo-Alexandria desert road to study the possibility of improving vegetative growth, yield and bunch quality through the application of shoot thinning on Black Monukka and Red Globe grapevines. The vines were ten-year-old, grown in a sandy loam soil, spaced at 2 X 3 meters apart, irrigated by the drip irrigation system, cane-pruned and trellised by Spanish Parron system. The vines were pruned during the second week of January for the two seasons of the study so as to leave (6 canes X 12 buds/cane). Ninety six uniform vines were chosen on the basis of their growth depending on weight of pruning and trunk diameter of the vine as indirect estimates for vine vigour. Each six vines acted as a replicate and each four replicates were treated by one of the following treatments for each cultivar under study.

Four treatments were applied before the beginning of the bloom as follows:

- Control (untreated vines)

- Removal of four main vegetative shoots

- Removal of eight main vegetative shoots

- Removal of twelve main vegetative shoots

Egypt. J. Hort. Vol. 41, No.2 (2014) 
The following parameters were measured to evaluate the tested treatments

Representative random samples of six bunches/vine were harvested at maturity when TSS reached about 16-17\% according to Tourky et al. (1995).

The following characteristics were determined:

Yield and physical characteristics of bunches

Yield/vine $(\mathrm{kg})$ was determined as number of bunches/vine $\mathrm{X}$ average bunch weight $(\mathrm{g})$. Average bunch weight $(\mathrm{g})$ and average bunch dimensions (length and width) $(\mathrm{cm})$ were also determined.

\section{Physical properties of berries}

Average berry weight $(\mathrm{g})$, average berry size $\left(\mathrm{cm}^{3}\right)$ and average berry dimensions (length and diameter) $(\mathrm{cm})$ were determined.

\section{Chemical properties of berries}

Total soluble solids (T.S.S.) percentage in berry juice was determined by hand refractometer and total titratable acidity expressed as tartaric acid (\%) was determined according to (A.O.A.C., 1985). Hence TSS /acid ratio and total anthocyanin of the berry skin (mg/100g fresh weight) according to Husia et al. (1965) were calculated.

Some characteristics of vegetative growth

At growth cessation, the following morphological and chemical determinations were carried out on 4 shoots / the considered vine:

- Average shoot diameter $(\mathrm{cm})$.

- Average shoots length $(\mathrm{cm})$

- Average leaf area $\left(\mathrm{cm}^{2}\right)$ of the apical $5^{\text {th }}$ and $6^{\text {th }}$ leaves using a CI-203Laser Area-meter made by CID, Inc., Vancouver, USA.

- Weight of pruning material $(\mathrm{Kg})$ at dormancy period (winter pruning).

Leaf content of total chlorophyll and cane content of total carbohydrates

- Leaf content of total chlorophyll were taken regularly in June , July and August measured by using nondestructive Minolta chlorophyll meter SPAD 502 of the apical $5^{\text {th }}$ and the $6^{\text {th }}$ leaves (Wood et al., 1992).

- Cane content of total carbohydrates (\%) was measured according to (Smith et al., 1956).

\section{Microclimate data}

Microclimate data of the vine (canopy temperature and light intensity) were estimated by Scheduler plant stress monitor Model R/O Consuitant made by Standard oil company, U.S.A. These parameters were recorded weekly at the fruit zone during the growing period from veraison stage to the harvest stage to determine the average of air temperature $\left(\mathrm{C}^{\mathrm{o}}\right)$ and light intensity (Watt). 
Statistical analysis

The complete randomized block design was adopted for this experiment. The statistical analysis of the present data was carried out according to Snedecor and Chocran (1972). Averages were compared using the new L.S.D. values at 5\% level.

\section{Results and Discussion}

\section{Yield and bunch physical characteristics}

Data in Table 1 revealed that all treatments of removal main vegetative shoots significantly affected the yield/vine and bunch weight as compared with untreated vines (control) in both seasons for the two cultivars under study. The maximum values were recorded on vines subjected to removal of twelve main vegetative shoots of Black Monukka grapevines and removal of eight main vegetative shoots of Red Globe grapevines. The beneficial effect of removal of twelve main vegetative shoots of Black Monukka grapevines and removal of eight main vegetative shoots of Red Globe grapevines on the yield could be ascribed mainly to the increase in bunch weight in the first season and the increase of number of bunches/vine beside the increase in bunch weight in the second season.

As far as bunch dimensions are concerned, it is evident that all removal of main vegetative shoots treatments significantly increased bunch dimensions as compared with the untreated vines. Removal of twelve main vegetative shoots of Black Monukka grapevines and removal of eight main vegetative shoots of Red Globe grapevines gave the best results in comparison with control in both seasons.

The positive effect of removal of some vegetative shoots treatments on increasing number of bunches/vine and yield can be explained through the following fact: shoot thinning improves canopy density, reduces shading, thereby stimulating of the reserved materials especially photosynthesis assimilates which leads to increases of carbohydrates in the remained shoots which increases in the coefficient of bud fertility, thereby increasing of number of bunches/vine and yield.

These results are in harmony with the finding of Naor and Gal (2002) who mentioned that cluster weight was lower in the high shoot number per vine of Sauvignon Blanc grapevines.

\section{Physical properties of berries}

Positive effects attributed to removal of main vegetative shoots treatments were also evident on physical characteristics of berries i.e. berry weight, size, length and diameter as compared to the control in both seasons for the two studied cultivars (Table 2). 
TABLE 1. Effect of vegetative shoot thinning on yield and bunch physical characteristics of

\begin{tabular}{|c|c|c|c|c|c|c|c|c|c|c|c|}
\hline \multicolumn{12}{|c|}{ Black Monukka and Red Globe grapevines in 2010 and 2011 seasons. } \\
\hline \multirow[t]{2}{*}{ Variety } & \multirow{2}{*}{\begin{tabular}{|c|} 
Characteristics \\
Treatments
\end{tabular}} & \multicolumn{2}{|c|}{$\begin{array}{l}\text { Yield/vine } \\
\text { (kg) }\end{array}$} & \multicolumn{2}{|c|}{$\begin{array}{c}\text { No. of } \\
\text { bunches }\end{array}$} & \multicolumn{2}{|c|}{$\begin{array}{c}\text { Average } \\
\text { bunch } \\
\text { weight (g) }\end{array}$} & \multicolumn{2}{|c|}{$\begin{array}{c}\text { Average } \\
\text { bunch } \\
\text { length }(\mathrm{cm})\end{array}$} & \multicolumn{2}{|c|}{ 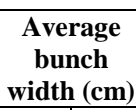 } \\
\hline & & 2010 & 2011 & 2010 & 2011 & 2010 & 2011 & 2010 & 2011 & 2010 & 2011 \\
\hline \multirow{4}{*}{$\begin{array}{l}\text { Black } \\
\text { Monukka }\end{array}$} & $\begin{array}{c}\text { Control } \\
\text { (untreated vines) }\end{array}$ & 11.57 & 12.49 & 18.9 & 19.6 & 612.9 & 637.9 & 28.3 & 28.5 & 13.5 & 14.1 \\
\hline & $\begin{array}{c}\text { Removal of four } \\
\text { main vegetative } \\
\text { shoots }\end{array}$ & 12.70 & 13.77 & 19.2 & 20.0 & 662.1 & 687.8 & 28.5 & 29.0 & 14.0 & 14.4 \\
\hline & \begin{tabular}{|c|}
$\begin{array}{c}\text { Removal of eight } \\
\text { main vegetative } \\
\text { shoots }\end{array}$ \\
\end{tabular} & 13.09 & 14.20 & 19.3 & 20.1 & 679.3 & 705.3 & 28.6 & 29.1 & 14.0 & 14.5 \\
\hline & $\begin{array}{c}\text { Removal of } \\
\text { twelve main } \\
\text { vegetative shoots }\end{array}$ & 13.54 & 14.72 & 19.4 & 20.2 & 698.9 & 727.5 & 28.9 & 29.2 & 14.2 & 14.6 \\
\hline \multicolumn{2}{|c|}{ new L.S.D. at $(0.05)=$} & 0.22 & 0.31 & N.S & 0.3 & 8.4 & 8.6 & 0.2 & 0.3 & 0.3 & 0.2 \\
\hline \multirow{4}{*}{$\begin{array}{l}\text { Red } \\
\text { Globe }\end{array}$} & $\begin{array}{c}\text { Control } \\
\text { (untreated vines) }\end{array}$ & 17.58 & 18.86 & 20.0 & 20.7 & 878.4 & 911.0 & 18.1 & 18.4 & 13.3 & 13.9 \\
\hline & $\begin{array}{c}\text { Removal of four } \\
\text { main vegetative } \\
\text { shoots }\end{array}$ & 18.12 & 19.65 & 20.1 & 21.0 & 900.0 & 935.3 & 18.3 & 18.5 & 13.5 & 13.9 \\
\hline & $\begin{array}{c}\text { Removal of eight } \\
\text { main vegetative } \\
\text { shoots }\end{array}$ & 18.61 & 20.29 & 20.2 & 21.3 & 919.4 & 950.6 & 18.4 & 18.6 & 13.9 & 14.1 \\
\hline & $\begin{array}{c}\text { Removal of } \\
\text { twelve main } \\
\text { vegetative shoots }\end{array}$ & 16.00 & 17.32 & 19.9 & 20.6 & 803.8 & 841.8 & 17.7 & 18.2 & 13.1 & 13.4 \\
\hline \multicolumn{2}{|c|}{ new L.S.D. at $(0.05)=$} & 0.14 & 0.19 & N.S & 0.2 & 9.3 & 8.2 & 0.1 & 0.2 & 0.2 & 0.3 \\
\hline
\end{tabular}

The highest values of those parameters were detected in case of vines treated with removal of twelve main vegetative shoots of Black Monukka grapevines and removal of eight main vegetative shoots of Red Globe grapevines.

The increase in berry weight and dimensions observed in summer pruning treatments can be interpreted in view of the fact that these treatments lead to the increase in photosynthetic activity of leaves. As a consequence of that, immigration of assimilates from leaves towards berries is enhanced (Winkler, 1965). The effect of shoot removal is related to the activation of photosynthesis inside the canopy of the vine through increasing light penetration and temperature, which induces an increase in sugars in the berries, raising its osmotic pressure and attraction force of water, thus improving physical berry properties.

These results are in accordance with those obtained by Reynolds et al. (1994) who showed that cluster and berry weight decreased with increasing shoot density. 
TABLE 2. Effect of vegetative shoot thinning on physical properties of berries of Black Monukka and Red Globe grapes in 2010 and 2011 seasons.

\begin{tabular}{|c|c|c|c|c|c|c|c|c|c|c|c|}
\hline \multirow[t]{2}{*}{ Variety } & \multirow{2}{*}{\begin{tabular}{|l} 
Characteristics \\
Treatments
\end{tabular}} & \multicolumn{2}{|c|}{$\begin{array}{c}\text { Average } \\
\text { berry weight } \\
\text { (g) }\end{array}$} & \multicolumn{2}{|c|}{$\begin{array}{c}\text { Average } \\
\text { berry size } \\
\left(\mathrm{cm}^{3}\right)\end{array}$} & \multicolumn{2}{|c|}{$\begin{array}{c}\text { Average } \\
\text { berry } \\
\text { length }(\mathrm{cm})\end{array}$} & \multicolumn{2}{|c|}{$\begin{array}{l}\text { Average } \\
\text { berry } \\
\text { diameter } \\
\text { (cm) }\end{array}$} & \multicolumn{2}{|c|}{$\begin{array}{c}\text { Average } \\
\text { berry shape } \\
\text { index }(\mathrm{cm})\end{array}$} \\
\hline & & 2010 & 2011 & 2010 & 2011 & 2010 & 2011 & 2010 & 2011 & 2010 & 2011 \\
\hline \multirow{4}{*}{$\begin{array}{l}\text { Black } \\
\text { Monukka }\end{array}$} & $\begin{array}{l}\text { Control } \\
\text { (untreated vines) }\end{array}$ & 4.25 & 4.39 & 4.15 & 4.29 & 2.23 & 2.27 & 1.66 & 1.69 & 1.35 & 1.34 \\
\hline & $\begin{array}{l}\text { Removal of four } \\
\text { main vegetative } \\
\text { shoots }\end{array}$ & 4.48 & 4.65 & 4.36 & 4.54 & 2.37 & 2.39 & 1.70 & 1.74 & 1.39 & 1.37 \\
\hline & $\begin{array}{l}\text { Removal of eight } \\
\text { main vegetative } \\
\text { shoots }\end{array}$ & 4.54 & 4.72 & 4.41 & 4.60 & 2.38 & 2.41 & 1.72 & 1.75 & 1.38 & 1.37 \\
\hline & $\begin{array}{l}\text { Removal of } \\
\text { twelve main } \\
\text { vegetative shoots }\end{array}$ & 4.70 & 4.90 & 4.57 & 4.76 & 2.41 & 2.44 & 1.73 & 1.76 & 1.39 & 1.38 \\
\hline \multicolumn{2}{|c|}{ new L.S.D. at $(0.05)=$} & 0.07 & 0.09 & 0.06 & 0.08 & 0.03 & 0.02 & 0.03 & 0.02 & N.S & N.S \\
\hline \multirow{4}{*}{$\begin{array}{l}\text { Red } \\
\text { Globe }\end{array}$} & $\begin{array}{l}\text { Control } \\
\text { (untreated vines) }\end{array}$ & 9.52 & 9.76 & 9.21 & 9.44 & 3.01 & 3.05 & 2.94 & 2.99 & 1.02 & 1.02 \\
\hline & $\begin{array}{l}\text { Removal of four } \\
\text { main vegetative } \\
\text { shoots }\end{array}$ & 9.67 & 9.93 & 9.35 & 9.59 & 3.06 & 3.09 & 2.97 & 3.04 & 1.03 & 1.01 \\
\hline & $\begin{array}{l}\text { Removal of eight } \\
\text { main vegetative } \\
\text { shoots }\end{array}$ & 10.09 & 10.31 & 9.72 & 9.94 & 3.10 & 3.13 & 3.01 & 3.09 & 1.03 & 1.02 \\
\hline & $\begin{array}{l}\text { Removal of } \\
\text { twelve main } \\
\text { vegetative shoots }\end{array}$ & 8.99 & 9.25 & 8.73 & 8.98 & 2.84 & 2.88 & 2.77 & 2.82 & 1.02 & 1.02 \\
\hline \multicolumn{2}{|c|}{ new L.S.D. at $(0.05)=$} & 0.11 & 0.14 & 0.09 & 0.13 & 0.03 & 0.05 & 0.04 & 0.03 & N.S & N.S \\
\hline
\end{tabular}

Chemical properties of the berries

Results presented in Table 3 revealed that all berry chemical characteristics, i.e. TSS, acidity, TSS/acid ratio and anthocyanin content of berry skin were significantly affected by all removal of main vegetative shoots treatments compared with untreated vines in both seasons for the two cultivars under study. Removal of twelve main vegetative shoots of Black Monukka grapevines and removal of eight main vegetative shoots of Red Globe grapevines resulted in the highest values of TSS percentage, anthocyanin content in berry skin and the lowest juice acidity.

Egypt. J. Hort. Vol. 41, No.2 (2014) 
TABLE 3. Effect of vegetative shoot thinning on chemical properties of berries of Black Monukka and Red Globe grapes in 2010 and 2011 seasons.

\begin{tabular}{|c|c|c|c|c|c|c|c|c|c|}
\hline \multirow[t]{2}{*}{ Variety } & \multirow{2}{*}{$\begin{array}{c}\text { Characteristics } \\
\text { Treatments }\end{array}$} & \multicolumn{2}{|c|}{ TSS (\%) } & \multicolumn{2}{|c|}{ Acidity (\%) } & \multicolumn{2}{|c|}{$\begin{array}{l}\text { TSS/acid } \\
\text { ratio }\end{array}$} & \multicolumn{2}{|c|}{$\begin{array}{c}\text { Anthocyanin } \\
\text { (mg/100g } \\
\text { F.W.) }\end{array}$} \\
\hline & & 2010 & 2011 & 2010 & 2011 & 2010 & 2011 & 2010 & 2011 \\
\hline \multirow{4}{*}{$\begin{array}{l}\text { Black } \\
\text { Monukka }\end{array}$} & $\begin{array}{l}\text { Control } \quad \text { (untreated } \\
\text { vines) }\end{array}$ & 16.2 & 16.5 & 0.51 & 0.48 & 31.76 & 34.38 & 34.2 & 35.8 \\
\hline & $\begin{array}{|lcr|}\begin{array}{l}\text { Removal } \\
\text { main }\end{array} & \text { of four } \\
\text { shoots } & \text { vegetative } \\
\end{array}$ & 16.5 & 16.7 & 0.48 & 0.46 & 34.38 & 36.30 & 40.3 & 42.2 \\
\hline & \begin{tabular}{|lll} 
Removal & of eight \\
main & vegetative \\
shoots & &
\end{tabular} & 16.6 & 16.7 & 0.47 & 0.46 & 35.32 & 36.30 & 41.5 & 42.8 \\
\hline & $\begin{array}{l}\text { Removal of twelve } \\
\text { main vegetative shoots }\end{array}$ & 16.8 & 16.8 & 0.46 & 0.45 & 36.52 & 37.33 & 41.7 & 44.0 \\
\hline \multicolumn{2}{|c|}{ new L.S.D. at $(0.05)=$} & 0.2 & 0.3 & 0.03 & 0.02 & 0.79 & 0.98 & 0.7 & 0.9 \\
\hline \multirow{4}{*}{$\begin{array}{l}\text { Red } \\
\text { Globe }\end{array}$} & $\begin{array}{ll}\begin{array}{l}\text { Control } \\
\text { vines) }\end{array} & \text { (untreated } \\
\end{array}$ & 17.1 & 17.4 & 0.54 & 0.52 & 31.67 & 33.46 & 29.0 & 31.1 \\
\hline & $\begin{array}{l}\text { Removal of four main } \\
\text { vegetative shoots }\end{array}$ & 17.2 & 17.5 & 0.53 & 0.51 & 32.45 & 34.31 & 29.6 & 32.3 \\
\hline & $\begin{array}{l}\text { Removal of eight main } \\
\text { vegetative shoots }\end{array}$ & 17.2 & 17.6 & 0.52 & 0.51 & 33.08 & 34.51 & 30.8 & 33.1 \\
\hline & $\begin{array}{l}\text { Removal of twelve } \\
\text { main vegetative shoots }\end{array}$ & 16.9 & 17.1 & 0.57 & 0.54 & 29.65 & 31.67 & 22.6 & 25.0 \\
\hline \multicolumn{2}{|c|}{ new L.S.D. at $(0.05)=$} & 0.3 & 0.2 & 0.02 & 0.01 & 0.68 & 0.74 & 0.5 & 0.7 \\
\hline
\end{tabular}

The positive influence of summer pruning treatments on berry chemical properties i.e. TSS\%, acidity\%, TSS/acid ratio in the grape juice as well as anthocyanin content of berry skin could be attributed to that shoot removal allows the light to penetrate the canopy of the vine resulting in an increase in the photosynthetic activity of the leaves inside the canopy and permits air circulation raising temperature inside the canopy, consequently, ripening is promoted through the positive influence on grape composition.

These results agree with the findings of Morris et al. (2004) who ensured that shoot thinning improved soluble solids in French-American Hybrid Grapes.

Some characteristics of vegetative growth

All removal of main vegetative shoots treatments were found to affect the characteristics of vegetative growth parameters (expressed as average shoot diameter, average shoots length, average leaf area and weight of pruning material) as compared with untreated vines in both seasons for the two cultivars under study (Table 4). The highest values of those parameters were detected in case of vines treated with removal of twelve main vegetative shoots of Black Monukka grapevines and removal of eight main vegetative shoots of Red Globe grapevines. 
The positive influence of the shoot thinning on improving of vegetative growth can be explained through the following fact: shoot thinning increased production of photosynthetically and physiologically efficient leaf area of the remained shoots which increased root density (Hunter and Le Roux, 1992) resulting in an appreciable increase in nutrient absorption and translocation of more carbohydrates to vegetative growth (Hunter and Visser, 1990).

\section{Leaf content of total chlorophyll and cane content of total carbohydrates}

Data presented in Table 5 revealed that leaf content of total chlorophyll and cane content of total carbohydrates were significantly increased by all removal of main vegetative shoots treatments compared with untreated vines in both seasons for the two cultivars under study. The highest values of those parameters were detected in case of vines treated with removal of twelve main vegetative shoots of Black Monukka grapevines and removal of eight main vegetative shoots of Red Globe grapevines.

TABLE 4. Effect of vegetative shoot thinning on morphological characteristics of vegetative

\begin{tabular}{|c|c|c|c|c|c|c|c|c|c|}
\hline \multirow[t]{2}{*}{ Variety } & \multirow{2}{*}{$\begin{array}{l}\text { Characteristics } \\
\text { Treatments }\end{array}$} & \multicolumn{2}{|c|}{$\begin{array}{l}\text { Average shoot } \\
\text { diameter }(\mathrm{cm})\end{array}$} & \multicolumn{2}{|c|}{$\begin{array}{c}\text { Average shoot } \\
\text { length }(\mathbf{c m})\end{array}$} & \multicolumn{2}{|c|}{$\begin{array}{l}\text { Average leaf } \\
\text { area }\left(\mathrm{cm}^{2}\right)\end{array}$} & \multicolumn{2}{|c|}{$\begin{array}{c}\text { Weight of } \\
\text { prunings } \\
(\mathrm{Kg})\end{array}$} \\
\hline & & 2010 & 2011 & 2010 & 2011 & 2010 & 2011 & 2010 & 2011 \\
\hline \multirow{4}{*}{$\begin{array}{l}\text { Black } \\
\text { Monukka }\end{array}$} & $\begin{array}{l}\text { Control (untreated } \\
\text { vines) }\end{array}$ & 0.95 & 0.98 & 155.6 & 159.0 & 178.7 & 182.6 & 5.89 & 6.14 \\
\hline & $\begin{array}{l}\text { Removal of four } \\
\text { main vegetative } \\
\text { shoots }\end{array}$ & 0.98 & 1.02 & 167.5 & 170.3 & 192.3 & 195.5 & 6.43 & 6.75 \\
\hline & $\begin{array}{l}\text { Removal of eight } \\
\text { main vegetative } \\
\text { shoots }\end{array}$ & 1.00 & 1.03 & 168.7 & 172.0 & 193.7 & 197.5 & 6.52 & 6.81 \\
\hline & $\begin{array}{l}\text { Removal of } \\
\text { twelve main } \\
\text { vegetative shoots }\end{array}$ & 1.03 & 1.09 & 171.8 & 174.4 & 197.3 & 200.2 & 6.63 & 6.97 \\
\hline \multicolumn{2}{|c|}{ new L.S.D. at $(0.05)=$} & 0.03 & 0.02 & 2.3 & 1.8 & 2.7 & 2.1 & 0.07 & 0.09 \\
\hline \multirow{4}{*}{$\begin{array}{l}\text { Red } \\
\text { Globe }\end{array}$} & $\begin{array}{l}\text { Control (untreated } \\
\text { vines) }\end{array}$ & 0.98 & 0.99 & 155.5 & 163.1 & 148.4 & 155.6 & 4.56 & 4.65 \\
\hline & $\begin{array}{l}\text { Removal of four } \\
\text { main vegetative } \\
\text { shoots }\end{array}$ & 0.99 & 0.99 & 157.6 & 164.6 & 150.4 & 157.1 & 4.59 & 4.69 \\
\hline & $\begin{array}{l}\text { Removal of eight } \\
\text { main vegetative } \\
\text { shoots }\end{array}$ & 1.00 & 1.02 & 160.3 & 168.4 & 153.0 & 160.7 & 4.68 & 4.76 \\
\hline & $\begin{array}{l}\text { Removal of } \\
\text { twelve main } \\
\text { vegetative shoots }\end{array}$ & 0.92 & 0.95 & 142.3 & 148.4 & 135.8 & 141.6 & 4.23 & 4.34 \\
\hline \multicolumn{2}{|c|}{ new L.S.D. at $(0.05)=$} & 0.02 & 0.01 & 2.5 & 1.9 & 2.8 & 2.5 & 0.05 & 0.04 \\
\hline
\end{tabular}

The relative increase in total carbohydrate content of canes observed in shoot thinning may be attributed to the high rate of shoot growth and wood ripening, since there existed a highly positive correlation between carbohydrate accumulation in the canes and the degree of wood ripening, in addition to the Egypt. J. Hort. Vol. 41, No.2 (2014) 
increase in the intensity of photosynthesis in leaves as well as the great accumulation of organic and mineral nutrients in favor of the rest tissues of the vines (Winkler, 1965). In addition, summer pruning increases solar radiation received by the leaves in the interior canopy, which by its turn increases photosynthetic activity of the leaves and consequently carbohydrate accumulation (Kliewer, 1981).

TABLE 5. Effect of vegetative shoot thinning on chemical characteristics of vegetative growth of Black Monukka and Red Globe grapevines in 2010 and 2011 seasons.

\begin{tabular}{|c|c|c|c|c|c|}
\hline \multirow{2}{*}{ Variety } & \multirow{2}{*}{\begin{tabular}{|l}
\multicolumn{1}{c}{ Characteristics } \\
Treatments
\end{tabular}} & \multicolumn{2}{|c|}{$\begin{array}{l}\text { Total chlorophyll } \\
\text { (SPAD) }\end{array}$} & \multicolumn{2}{|c|}{$\begin{array}{c}\text { Total carbohydrates } \\
(\%)\end{array}$} \\
\hline & & 2010 & 2011 & 2010 & 2011 \\
\hline \multirow{4}{*}{$\begin{array}{l}\text { Black } \\
\text { Monukka }\end{array}$} & Control (untreated vines) & 34.3 & 38.2 & 24.7 & 26.2 \\
\hline & $\begin{array}{l}\text { Removal of four main } \\
\text { vegetative shoots }\end{array}$ & 38.0 & 41.8 & 26.3 & 27.8 \\
\hline & \begin{tabular}{|l}
$\begin{array}{l}\text { Removal of eight main } \\
\text { vegetative shoots }\end{array}$ \\
\end{tabular} & 38.7 & 42.5 & 26.9 & 28.4 \\
\hline & $\begin{array}{l}\text { Removal of twelve main } \\
\text { vegetative shoots }\end{array}$ & 39.6 & 44.3 & 28.1 & 29.7 \\
\hline \multicolumn{2}{|c|}{ new L.S.D. at $(0.05)=$} & 0.4 & 0.9 & 0.7 & 0.6 \\
\hline \multirow{4}{*}{$\begin{array}{l}\text { Red } \\
\text { Globe }\end{array}$} & Control (untreated vines) & 40.5 & 42.3 & 29.3 & 32.6 \\
\hline & $\begin{array}{l}\begin{array}{l}\text { Removal of four main } \\
\text { vegetative shoots }\end{array} \\
\end{array}$ & 41.4 & 43.6 & 30.3 & 33.1 \\
\hline & $\begin{array}{l}\text { Removal of eight main } \\
\text { vegetative shoots }\end{array}$ & 42.8 & 44.9 & 31.3 & 35.4 \\
\hline & \begin{tabular}{|l}
$\begin{array}{l}\text { Removal of twelve main } \\
\text { vegetative shoots }\end{array}$ \\
\end{tabular} & 37.6 & 39.9 & 27.9 & 30.9 \\
\hline \multicolumn{2}{|r|}{ new L.S.D. at $(0.05)=$} & 0.6 & 0.5 & 0.7 & 0.9 \\
\hline
\end{tabular}

These results are in accordance with those obtained by Ruffner et al. (1990) and Hunter et al. (1994) who found that shoot removal had generally higher carbohydrate accumulation in the remained shoot leaves, which corresponds to the enhancement in photosynthetic activity.

\section{Microclimate data}

Results presented in Table 6 revealed that all microclimate data of the vine, i.e. (air temperature and light intensity) were significantly affected by all removal of main vegetative shoots treatments compared with untreated vines in both seasons for the two cultivars under study. Vines treated with removal of twelve main vegetative shoots of Black Monukka and Red Globe grapevines resulted in the highest values of air temperature and the highest light intensity as compared to the untreated vines (control). 
TABLE 6. Effect of vegetative shoot thinning on microclimate data of Black Monukka and Red Globe grapevines in 2010 and 2011 seasons.

\begin{tabular}{|c|c|c|c|c|c|}
\hline \multirow{2}{*}{ Variety } & \multirow{2}{*}{$\begin{array}{c}\text { Characteristics } \\
\text { Treatments }\end{array}$} & \multicolumn{2}{|c|}{ Air temperature $\left(C^{o}\right)$} & \multicolumn{2}{|c|}{$\begin{array}{c}\text { Light intensity } \\
\text { (Watt) }\end{array}$} \\
\hline & & 2010 & 2011 & 2010 & 2011 \\
\hline \multirow{4}{*}{$\begin{array}{c}\text { Black } \\
\text { Monukka }\end{array}$} & Control (untreated vines) & 27.0 & 27.1 & 60.3 & 61.8 \\
\hline & $\begin{array}{l}\text { Removal of four main } \\
\text { vegetative shoots }\end{array}$ & 27.3 & 27.4 & 64.1 & 65.5 \\
\hline & $\begin{array}{l}\text { Removal of eight main } \\
\text { vegetative shoots }\end{array}$ & 27.5 & 27.8 & 69.7 & 68.9 \\
\hline & $\begin{array}{l}\text { Removal of twelve main } \\
\text { vegetative shoots }\end{array}$ & 27.9 & 28.1 & 72.5 & 73.2 \\
\hline \multicolumn{2}{|c|}{ new L.S.D. at $(0.05)=$} & 0.2 & 0.2 & 0.3 & 2.7 \\
\hline \multirow{4}{*}{ Red Globe } & Control (untreated vines) & 27.1 & 26.9 & 62.5 & 60.9 \\
\hline & $\begin{array}{l}\text { Removal of four main } \\
\text { vegetative shoots }\end{array}$ & 27.2 & 27.1 & 65.4 & 64.2 \\
\hline & $\begin{array}{l}\text { Removal of eight main } \\
\text { vegetative shoots }\end{array}$ & 27.4 & 27.3 & 70.8 & 69.1 \\
\hline & $\begin{array}{l}\text { Removal of twelve main } \\
\text { vegetative shoots }\end{array}$ & 27.7 & 27.6 & 74.3 & 73.6 \\
\hline \multicolumn{2}{|c|}{ new L.S.D. at $(0.05)=$} & 0.1 & 0.1 & 0.2 & 2.9 \\
\hline
\end{tabular}

The positive effect of removal of some vegetative shoots treatments on increasing number of bunches/vine and yield can be explained through the following fact: shoot thinning improves canopy density, reduces shading and leaf layer number, thereby increasing proportion of canopy gaps, exterior leaves and the penetration of sunlight and ventilation inside the canopy.

The obtained results are in line with those of Gubler \& Morios (1987), Kliewer et al. (1988), Percival et al. (1994) and Dokoozlian \& Kliewer (1995) who found that the dense canopy of the control vines decreased the penetration of sunlight and ventilation inside the canopy.

\section{Conclusion}

All treatments were effective in increasing the number of bunches/vine, average bunch weight and yield. Removal of twelve main vegetative shoots of Black Monukka grapevines and removal of eight main vegetative shoots of Red Globe grapevines improved the physical characteristics of the bunches, physical and chemical properties of berries, morphological characteristics of vegetative growth, leaf content of total chlorophyll and cane content of total carbohydrates as compared with the control.

Egypt. J. Hort. Vol. 41, No.2 (2014) 


\section{References}

Abd El-Wahab, W.A., Mohamed, S.M. and El-Gendy, R.S. (1997) Effect of summer pruning on bud behavior and bunch characteristics of Thompson Seedless grapevines. Bull. Fac. Agric. Univ. Cairo, 48, 351-378.

Alia, H.I., Mervet, A.A. and Abd El-Hady, M.A. (2001) Response of Red Roomy grapevines to summer pruning. J. Agric. Sci. Mansoura Univ., 26 (9), 5641-5649.

Association of Official Agricultural Chemists (1985) "Official Methods of Analysis", A.O.A.C., Benjumin Franklin Station, Washington, D. C. N. S. A. pp 440-510.

Dokoozlian, N.K. and Kliewer, W.M. (1995) The light environment within grapevine canopies. I. Description and seasonal changes during fruit development. Amer. J. Enol. Vitic., 46, 209- 218.

Freese, P.P. (1988) Canopy modification and fruit composition. Proc. Second Int. Symp. Auckland, Newzealand. Nz. Soc. for Vitic. and Qenal 134-136.

Gaser, A.S.A. (2006) Evaluation of some newly-introduced grape cultivars under Egyptian conditions with special stress on some morphological characteristics. $J$. Agric. Sci. Mansoura Univ., 31(11), 7305-7320.

Gubler, W.D. and Marois, J.J. (1987) Control of bunch rot in grape with canopy management. Plant Disease, 71, 599-601.

Hunter, J.J. and Le Roux, D.J. (1992) The effect of partial defoliation on development and distribution of roots of Vitis vinifera L. cv. Cabernet Sauvignon grafted onto rootstock 99 Richter. Am. J. Enol. Vitic., 43, 71-78.

Hunter, J.J. and Visser, J.H. (1990) The effect of partial defoliation on growth characteristics of Vitis vinifera L. cv. Cabernet Sauvignon. I. Vegetative growth. $S$. Afr. J. Enol. Vitic., 11, 18-25.

Hunter, J.J., Skrivan, R. and Ruffner, H.P. (1994) Diurnal and seasonal physiological changes in leaves of Vitis vinifera L.: $\mathrm{CO}_{2}$ assimilation rates, sugar levels and sucrolytic enzyme activity. Vitis, 33, 189-195.

Husia, C.L., Luh, B.S. and Chichester, C.D. (1965) Anthocyanin in free stone peach. $J$. Food Science, 30, 5-12.

Kliewer, W.M. (1981) Grapevine physiology: How does a grapevine make sugar? Leaflet 21231. division of Agricultural Sciences. Univ. Calif.

Kliewer, M.W., Marois, J.J., Bledsoe, A.M., Smith, S.P., Benz, M.J. and Silvestroni, O. (1988) Relative effectiveness of leaf removal, shoot positioning, and trellising for improving wine grape composition. In: Proc. $2^{\text {nd }}$ Int. Symp. Cool Climate Viticulture and Oenology. pp. 123-126. New Zealand Society for Viticulture and Oenology, Auckland.

Marwad, I.A. (2002) Comparative studies of five seedless grape cultivars under conditions of Qalubia governorate, Egypt. Egypt. J. Appl. Sci., 17 (1), 307-326.

Egypt. J. Hort. Vol. 41, No.2 (2014) 
Morris, J.R., Main, G.L. and Oswald, O.L. (2004) Flower Cluster and Shoot thinning for crop control in French-American Hybrid Grapes. Am. J. Enol. Vitic., 55, 423-426.

Naor, A. and Gal, Y. (2002) Shoot and cluster thinning influence vegetative growth, fruit yield and wine quality of "Sauvignon blanc" grapevines. J. Amer. Soc. Hort. Sci., 127(4), 628-634.

Percival, D.C., Fiher, K.H. and Sullivan, J.A. (1994) Use of fruit zone leaf removal with Vitis vinifera L. cv. Riesling grapevines. I- Effects on canopy structure, microclimate, bud survival, shoot density and vine vigor. Am. J. Enol Vitic., 45 (2), 123-132.

Reynolds, A.G. (1989) Impact of pruning strategy, cluster thinning and shoot removal on growth, yield and fruit composition of low De Chaunac vines. Canadian J. plant Sci., 69(1), 260-275.

Reynolds, A.G., Edwards, C.G., Wardle, D.A., Webster, D.R. and Dever, M. (1994) Shoot density affects "Riesling" grapevines. II. Wine composition and sensory response. J. Amer. Soc. Hort. Sci., 119, 881-892.

Reynolds, A.G., Molek, T. and De Savigny, C. (2005) Timing of Shoot Thinning in Vitis vinifera: Impacts on Yield and Fruit Composition Variables. Am. J. Enol. Vitic., 56, 4 343-356.

Ruffner, H.P., Adler, S. and Rast, D.M., (1990) Soluble and wall associated forms of invertase in Vitis vinifera. Phytochemistry, 29, 2083-2086.

Smart, R.E. (1988) Shoot spacing and canopy light microclimate. Amer. J. Enol. Vitic. 39, 325-333.

Smith, F., Gilles, M.A., Hamilton, J.K. and Gedess, P.A. (1956) Colorimetric methods for determination of sugar and related substan. Anal. Chem., 28,350.

Snedecor, G.W. and Cochran. W.G. (1972) "Statistical Methods" $6^{\text {th }}$ ed., The Iowa State Univ. Press . Ames., Iowa, U.S.A., pp. 50.

Tourky, M.N., El-Shahat, S.S. and Rizk, M.H. (1995) Effect of Dormex on fruit set, quality and storage life of Thompson seedless grapes (Banati grapes) J. Agric. Sci., Mansoura Univ., 20(12), 5139-5151.

Winkler, A. (1965) "General Viticulture", Univ. Calif. Press, Barkely and Loss Angeles.

Wolf, T.K., Zoechlein, B.W., Cook, M.K. and Coreingham, C.K. (1990) Shoot topping and ethephon effects on White Riesling grapes. Amer. J. Enol. Vitic., 41(4), 330-341.

Egypt. J. Hort. Vol. 41, No.2 (2014) 
Wood, C.W., Reeves, D.W. and Himelrick, D.G. (1992) Relationships between chlorophyll meter readings and leaf chlorophyll concentration. $\mathrm{N}$ status and crop yield. A review: Proc. Agro. Soc. N. Z., 23,1-9.

(Received 10/8/2014; accepted 5/10/2014)

\section{تأثير خف الأفرع الخضرية على النمو والمحصول وجودة الثمار

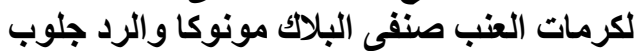

$$
\text { غادة شكر شاكر ـ معوث البساتين ـ مركز البحوث الزر اعية ـ القاهرة ـ مصر. }
$$

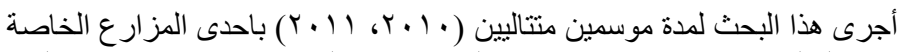

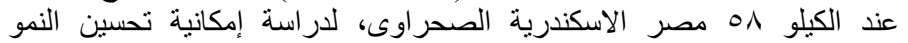

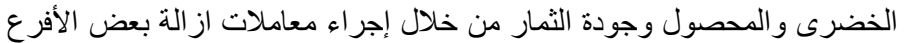

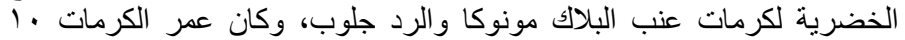

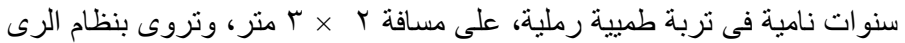

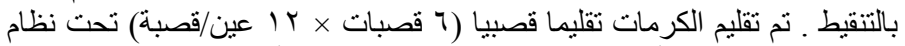

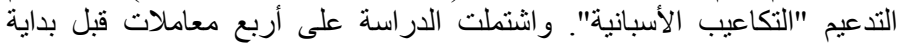

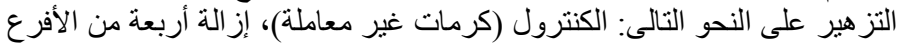

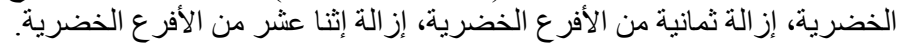

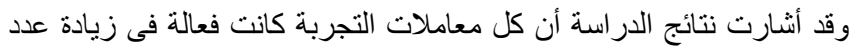

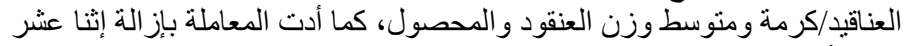

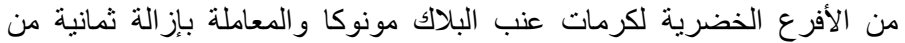

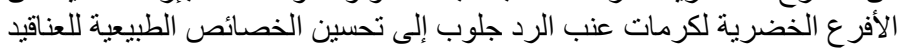

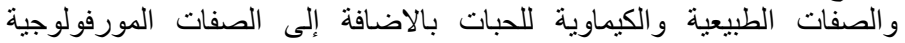

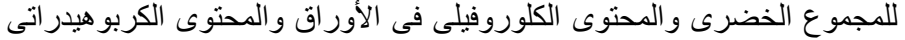
فى القصبات مقارنة بالكنترول.

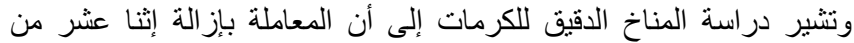

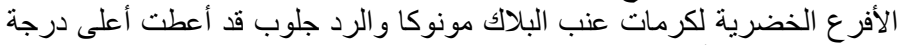
حرارة الهو اء مع أعلى نفاذية للضوء داخد داخل الكرمة بالمقارنة بالكنترول. 